\title{
Chapter 12: Reforming Australian Governance: Old States, No States or New States?
}

\section{Kenneth Wiltshire}

\section{Introduction}

Australia's creaking federalism is back in the news, as events cause us to reflect on the appropriateness of our system of governance.

There is nothing surprising in this, since federalism is supposed to be a dynamic form of government. We see such dynamism also in the international scene. Not so long ago, Belgium moved from being a unitary to a federal country to accommodate cultural and linguistic differences. Great Britain established new regional assemblies in Scotland and Wales and devolved some central powers to them. Italy and Spain have experienced a resurgence of regionalism driven by cultural and economic forces, and the European Union itself has ignited the aspirations of regions within its member states with its generous subsidies and grants channelled directly for sub-national regions, occurring at the same time as the implementation of its general policies on subsidiarity and mutual recognition of laws. Canada fairly recently (1999) created a new self-governing territory - Nunavut - for its Inuit peoples. Countries in conflict and post-conflict situations have often turned to federalism principles as a way of combining local identity with unity, such as solutions proposed for Cyprus, Jerusalem and Kosovo. Even strong growth economies with unitary systems of government, like Japan, China, Thailand and Indonesia, experience regional tensions as they grow, and look to federal finance arrangements to address their need to share wealth creation between urban and rural or coastal regions, and to achieve a fair balance in tax and expenditure sharing between central and regional governments.

The key lesson in all of this contemporary experience is that systems of governance, to survive, need to be dynamic and not static. Change is a normal circumstance. Both unitary and federal systems alike are pursuing unity with diversity, underpinned by sound governance arrangements to protect the economic and cultural sustainability of their regions, which is now accepted as the price of nationhood.

Any attempt to rethink Australian governance arrangements would do best to revisit the approach of Henry Parkes, the key leader of the federation movement, who called the founders to that historic Constitutional Convention in Sydney 
in 1891. Parkes had made overtures and visits to the other colonies to engage in consultation well before that seminal event and, in his famous Tenterfield Oration, he made it clear that the achievement of national unity was his underlying motive. As he put it so eloquently, 'the crimson thread of kinship runs through us all'. When the Convention finally gathered in Sydney, Parkes began the proceedings by putting forward a set of principles for discussion and consensus before any work might begin on constitutional design and drafting (see Quick and Garran 1901; Wiltshire 1991). The two great lessons from this experience, for any ongoing reform of governance, are to ensure that the prime goal is to retain a sense of nationhood, and to agree on basic principles before becoming enmeshed in debates about maps, boundaries, functions, taxes, and roles.

\section{The historical context}

When the Constitution was being written in the 1890s, Australia was not yet a nation. The founders tended to see it as six separate economies and societies, which was natural given such a vast continent, so sparsely populated. We are told that some of the founders communicated in Morse code. The landscape of our governance, as depicted in the Constitution which was finally adopted in 1901, reflects this. The boundaries of the States, which followed those of the existing colonies, had no particular economic or social significance, although they did take some account of geographical features. The River Murray was the obvious example, serving as the border between the two main States (NSW and Victoria), along with the Queensland/NSW border in its coastal and mountain regions. But, by contrast, other boundaries simply followed latitudinal and longitudinal parallels, including the boundary of Western Australia, whose origin commenced with global lines of demarcation originally drawn between Spain and Portugal, and reinforced by Papal decree, in 1494 (see Brown 2003: 42-5; Taylor 2006: 26-31). Even the more natural boundaries have since proved inappropriate, giving rise to no end of disputes over riparian rights of one kind or another from that day to this - an aspect well known to the good citizens of Corowa where the key original Constitutional Convention was held in 1893 to kick start the path towards federation, from which the politicians had strayed after their initial bursts of drafting in 1890-91.

The Australian Constitution is a blend of the Westminster model of government to delineate the separation of powers, and the American federal design for the division of powers between the Commonwealth and the States. Switzerland provided the inspiration, if not the actual model, for the process of amending the Constitution, which is by referendum of all the people - a testimony to the importance of people power in the continual evolution of our governance. Indeed Australia is one of the few nations in the world which came into existence by a vote of its people. 
In designing the federal aspects, the founders were following thought processes similar to those of the American founders, who saw the federal design as a 'layer cake' with each level of government separate and sovereign to the maximum extent, each with its own list of revenue sources and expenditure functions, despite some inevitable concurrent powers. Like the Americans, the Australian founders also tried to design a federal system where the national government would have a narrow paddock in which to exercise its limited jurisdiction in a list of enumerated powers, and the States would enjoy all the residual powers. A person from Mars arriving on Earth today, reading the Australian Constitution, would assume that it was the States that ran this country.

Of course, some modern day functions of government which were not issues in the nineteenth century are not written in the Constitution at all - for example, management of the environment. Some were curiously divided between the levels, for example in industrial relations, reflecting the six economies' slant and causing no end of confusion ever since. Still other functions were left vague, e.g. external affairs and finance. This reflected the lack of need for precision in these fields at this time, although many prescient founders predicted the turmoil this would cause in the future, the most notable being Deakin's famous vision that the States would become bound to the 'Chariot Wheels of the Commonwealth' (La Nauze 1979).

Local government was very slow in appearing in Australian history, its establishment coming mainly after that of the colonial governments, quite contrary to the experience of most nations which were built on a foundation of local government (Spann 1973). Local government was barely considered by the founders, and does not figure in the Australian Constitution at all (Aulich and Peitsch 2002; Brown 2002; Bell this volume).

However the founders were certainly familiar with concepts of regionalism. The very difficulty of getting all colonies to join the federal movement, especially Western Australia and Queensland, had alerted them to the possibility of future endeavours to fragment their creation. The famous Section 96 of the Constitution was inserted precisely to allow for the special circumstances of any State to be addressed through Commonwealth Grants, thereby anticipating threats of secession, particularly in Western Australia. Section 96 says that the Commonwealth Parliament may make grants to the States on such terms and conditions as it sees fit. It was intended solely as an emergency measure to bail out a State in financial difficulties through no fault of its own, but has become one of the most entrenched powers for the Commonwealth, now enjoying a general application (Commonwealth Grants Commission 1995). It also laid the foundation for the principle of Horizontal Fiscal Equalisation, based on the seminal Australian interpretation of 'equity', to the effect that every Australian 
is entitled to similar standards of government services no matter where they live. Thus the concept of unity in diversity was born.

The founders also had to accommodate other elements of regional fragmentation. Section 7 of the Constitution, allowing for states to divide themselves into regions for Senate elections (but since effectively rescinded by Parliament), was a condition of securing the support of North Queensland, and perhaps other regions, for federation. Finally, in Chapter VI, the Constitution also contained a built-in mechanism for the creation of new states, recognising the pressure not only from North and Central Queensland but other regions like New England, the Riverina and the Western Australian Goldfields for their own identity.

\section{The regionalism trail}

Since 1901 there have been numerous initiatives to introduce regions into various aspects of Australia's governance. For the most part these have been 'top-down' attempts by state governments, and occasionally the Commonwealth Government, to establish regions for their own service delivery, accompanied by some decentralisation of their financial, human, and physical resources to those regions. Rarely have these measures been accompanied by any real devolution of power to the regions; mainly they have been just administrative arrangements. Local governments have, from time to time, swelled up into regional groupings for some purpose/ program, in a bottom up approach, but where this has happened it has been predominantly in response to some financial carrot being offered by one or both of the other two levels of government and their enthusiasm for regional perspectives has withered when the carrot was taken away.

Australian local governments do not spontaneously think regionally (see e.g. Jones 2003). This is somewhat understandable given their often unviable size and shape, their narrow and precarious revenue base, and the exponential growth in their responsibilities. More recently they have become victims of cost shifting to them by the other levels of government which are adept at transferring functions to local government but usually without compensatory funding or revenue-raising capacity. State governments look upon them with disdain, giving true feeling to the maxim that, constitutionally, local government is the 'creature' of state governments - many state governments have established Quangos of their own rather than allow local governments deliver a service on a regional basis. Local government also did itself a great disservice through its disunity in the referenda of 1974 and 1988, which presented the possibility of local government being recognised in the Australian Constitution, but which were lost. Furthermore, Australian local government was never a formal partner in the nation's intergovernmental relations until the advent of the Fraser Government's New Federalism which saw local government given a strong role on the Advisory Council on Intergovernmental Relations, and the Hawke Government's New Federalism which saw local government win a place in the 
Council of Australian governments (COAG). Local government also received strong encouragement from the Constitutional Centenary Foundation, a non-government body established in 1991 to ascertain the need for constitutional reform leading up to the Centenary of Australian federation in 2001.

The two great Australian experiments in regionalism during the twentieth century were during the post-war reconstruction period (1944-49), and the period of the Whitlam government (1972-75) which took the Commonwealth into urban and regional issues in a new venture beyond conventional thinking about the role of the national government. The approach of the Whitlam government is particularly instructive as it involved ventures into functions not normally the constitutional preserve of the Commonwealth Government, including urban and regional development, the environment, distribution of funding on a regional basis, some by-passing of state governments by extra-constitutional means to give funding directly to local governments, and an enhanced role for local government with a new Horizontal Fiscal Equalisation scheme for local government alone. Considerable research went into designing a new regional structure based on criteria for the definition of regions and their suitability for government policy (see e.g. DURD 1973).

Apart from these two major initiatives, which really did see regional governance in play in Australia, there have also been many other proposals put forward by political parties and interest groups to divide Australia into regions for various purposes, usually accompanied by suggestions that state governments should be abolished. The number of regions proposed has usually varied between 35 and 65 , but their constitutional status and the implications for the composition of the Australian Senate, have rarely been spelt out.

\section{Towards new thinking on regions: recognising federal centralism}

For any new and serious approach to contemplate the creation of regions in Australia, there are a number of necessary steps in the design process. First of all, it is essential to acknowledge the profound centralisation which has occurred in the Australian federation. The modern reality of the governance landscape is quite the opposite of the intention of the founders of the Constitution, and the Commonwealth Government dominates the scene. This has occurred through at least six means.

First, there has been amendment of the Constitution itself. Although only eight out of 46 referendum proposals have been passed, at least three of these have given significant powers to the Commonwealth - the 1927 Amendment to Section 105 on public loan raising, the 1946 amendment to Section 51 giving the Commonwealth social welfare powers, and the largest 'yes' vote in Australian history $(90 \%)$, in 1967 , to give the Commonwealth a role in indigenous affairs. 
Secondly, there have been High Court judgements. Especially in the interpretation of taxation powers and the use of the corporations and external affairs powers, the Court has progressively handed significant powers to the Commonwealth Government. This has been due not so much to the leanings of the judges themselves, as the body of conspiracy theory would suggest. It has more to do with the recognition by the judges of the impact of two particular trends: globalisation, which requires Australia to speak with one voice in international forums, and national development, in which the sheer existence of a national economy, transport and communications system, and mobile populations and resources, sees the need for stronger national solutions and approaches. Both these trends have portended stronger powers for the Commonwealth Government. They have also seen the judges prepared to adopt less fundamentalist approaches to the wording of the Constitution and embrace the need for dynamic interpretation, despite the oft-heard criticism that this is creative law making by the judiciary and hence outside its proper role.

Thirdly, Commonwealth power has grown as a result of the nature of federal financial relations. This is the arena where the greatest centralisation has been evident. As a result of the 1927 amendment on loan raising, the uniform tax arrangements entered into during World War II, and several High Court judgements involving indirect taxation, the Commonwealth Government now collects over $70 \%$ of all the taxation revenue in Australia - including control of income tax, GST, and all the main indirect taxes. It also has had the dominant role in loan-raising powers and monetary policy. So the States, which are responsible for about half of all public expenditure in Australia, raise less than $20 \%$ of public revenue from a very narrow tax base. As a result, they are extremely dependent on grants from the Commonwealth Government. This is the situation known as Vertical Financial Imbalance, and it is worse in Australia than in any other federation in the world. It means that, on average, the States are dependent on Commonwealth transfers for half of all their revenue (higher for smaller States like Tasmania and the Territories). To make things worse, the Commonwealth attaches conditions to half of all those grants it gives the States. Local government is in an even more precarious position, raising only around $5-6 \%$ of all public revenue, and being highly dependent on transfers from state and Commonwealth Governments to survive, with most of those transfers having conditions attached.

Fourthly, 'executive federalism' has also contributed to the growth of Commonwealth influence. Executive federalism is a product of the era of 'co-operative federalism', the foundation of which was laid in the aftermath of the Great Depression, as all levels of government struggled together to revive the nation. In modern Australia, the majority of public functions now involve at least two levels of government (e.g. education) and often three levels (e.g. health, transport). As a result, the 'layer cake' model of federalism desired by 
the founders has long since ceased to exist, just as today it does not exist in any federal system. In Germany, for example, the constitution was rewritten after World War II, with a heavy shaping hand from the Allied powers, to recognise this design fault in older federal systems and instead lay much emphasis on Joint Tasks and continuous sharing of revenue and expenditure functions, under the strong supervision of the Bundesrat (which is a true States' House).

In Australia, too, it is no longer possible to assign whole functions of government to just one level of government. Rather, federalism is more like a 'marble cake' where the functions of government swirl around, engulfing two or three levels. Geoffrey Sawer (1976) called it 'organic federalism', a reminder to us once again of the prescience of those founders who predicted that once the omelette had been cooked, the eggs would lose their identity. Today, the effort to make this work has led to the concept and industry of executive federalism, manifest in over 350 intergovernmental agreements, watched over by meetings of some 41 Ministerial Councils across all fields of government, at the apex of which stands COAG, mentioned earlier. Executive federalism covers over one-third of all public sector activity in Australia. It has generally increased the power of the Commonwealth Government, especially by giving it access to constitutional areas not normally its terrain, including school education, hospitals, roads, agriculture, and the capacity through its fiscal supremacy to drive public policy in these arenas.

The reasons why these intergovernmental agreements have been initiated are instructive. They include:

- to achieve uniformity in the administration of a common functional area;

- to avoid overlapping in the provision of administrative services;

- to respond to the situation of vertical fiscal imbalance whereby the Commonwealth has the funding but the States have the functional power;

- to cope with the mobility of resources, human and financial, across state boundaries;

- to ensure accessibility to public resources for all Australians, no matter where they live;

- to disseminate information, or even exhortation, on vital areas of public interest, including where national solidarity is essential; and

- to pool resources between governments for challenges too big for one level to undertake, including major research efforts and, potentially, involving complementary action between the levels (as with the handling of emergencies. See Wiltshire 1977, 1980; ACIR 1981).

Although this plethora of activity, with its labyrinth of Councils and Committees and funding agreements, may well have begun under the rubric of 'co-operative' federalism, the tone is now quite different. Almost all of these arenas are now hot beds of dispute and wrangling, where the States fight the Commonwealth 
over funding and policy directions, occasionally even refusing to accept funding from the Commonwealth, which in turn accuses the States of mismanaging the funding they are given and not honouring the terms of the agreements.

A fifth influence has been the emergency powers and 'overrides' possessed by the Commonwealth. All federal constitutions make provision for national emergencies whence the national government is able to assume significant additional powers, including from state governments. This has happened in Australia in war time, and in other instances. Less formal but similar effects have come when Australia has faced major challenges which have given legitimacy to the national government in accumulating more power. Examples have included rampant inflation, energy crises, and terrorism.

Finally, unconstitutional action contributes to the strength of central power. From time to time governments stray into territory which is not really their preserve, but nobody mounts a challenge. The CSIRO is an example since the Commonwealth does not really have constitutional power in its domain. The same is true for the various international activities undertaken by state governments, including their elaborate trade and migration offices around the world.

The greatest evil of these trends towards centralism, especially the fiscal and executive federalism aspects, is the way they have distorted accountability in the Australian federal system. It has become extremely difficult for the citizen to apportion credit or blame to the appropriate level of government, thus creating a recipe for constant buck-passing from one level to another.

From 1996 to 2007, the centre of gravity in Australian politics also continued to shift towards Canberra through a most unexpected influence: the centralism of the Howard Coalition government. Once upon a time the Liberal Party was the champion of states' rights and decentralisation of power. The Howard government completely reversed this ideology, and became arguably at least as centralist as any Labor government has been. This phenomenon was facilitated to some extent by the fact that all the State and Territory Governments came to be held by Labor governments during the past decade, but that is not the only explanation. Enjoying the fruits of office and burgeoning revenue, with each successive re-election the Howard government rigorously pushed through its long-held ideological and policy agenda, even if this meant overriding state governments. After unexpectedly gaining control of the Senate at the 2004 election, the momentum quickened even further. In 2006, even before the definitive 'WorkChoices' High Court decision enabled the Commonwealth Government to override state industrial relations powers using the corporations power, the Commonwealth Attorney-General made it plain that if successful, this power would be employed in a similar manner to override other state powers. 
The tactics of the Howard government have included pleas for uniformity, accountability and choice, which have fallen on fertile ground in an electorate which has grown tired and wary of state governments who deliver none of these goals and have proven inept at delivering their basic responsibilities of health care, school education, law and order, water, and infrastructure. Little wonder recent surveys show considerable disdain amongst both rural and urban citizens regarding their perceptions of state governments (for the NSW position, see Gray and Brown this volume). The modalities of 'Howard centralism' have included:

- conditional funding;

- bypassing states;

- overriding states;

- treating states as service deliverers rather than policy partners; and

- introducing purchaser/provider models where states would be just one of the bidders for Commonwealth funding.

So, as Greg Craven has said, every major Australian political party is centralist now (Craven 2005, 2006). The trend will be almost impossible to reverse. This is the context in which any new moves towards regionalism will take place.

\section{Components of an effective federal-regional response}

The centralising trend in Australian federalism, while sensible in some arenas, means that a whole new approach is needed towards rebuilding a sensible system of government, including reviving the advantages of federalism. This could be by refashioning traditional ideas of states' rights, by substituting a viable new national framework of regional devolution, using central power to more effectively decentralise. Given the recognised limitations of state and local government in the existing system, it is not simply a matter of trying to wind back the clock, or redistribute resources among existing institutions.

Instead, what is needed is a coherent national approach, the heart of which must be a viable, effective framework of regional governance. If we are serious about federalism, this should include 'general-purpose' regional government which is large enough to be viable and adaptive in fulfilling a wider range of policy needs than current local government, but operating at a scale more aligned with the real communities of interest of constituents, than can ever be the case with most present state or territory governments. To truly rebuild an effective federal system, of course, the fact that Australians live, work and govern themselves using these regions should also be recognised and legally protected in the Constitution. Whether or how the other existing levels of government would need to be reformed, to work in with an effective regional governance system, are secondary issues to consider once the primary need for a new framework is accepted. 
The design of any new regional governance framework would have three fundamental components: (1) the functions or tasks which such regions would perform; (2) the determination of the boundaries of those regions; and (3) measures to ensure that the regions are sustainable.

Approaching the first issue of tasks, it is instructive to turn to previous endeavours which have been made in Australia to unscramble the omelette of federalism and identify the functions which are appropriate for each level of government. The most comprehensive attempt was by the Australian Advisory Council on Intergovernmental Relations (ACIR 1981) which scoured the economic and political/administrative literature, and global experience, to identify criteria which would help in the assignment of functions to levels of government. The research was aided by similar efforts which had been made in Canada (the Rowell Sirois Commission 1940), and the USA (the Kestnbaum Commission 1955) as well as two seminal Australian reviews - the 1927-29 Royal Commission on the Constitution, and a 1958 Parliamentary Committee Review of the Australian Constitution (Australia 1929, 1958).

The key lesson from this exercise was that it was no longer appropriate to try to assign whole functions to particular levels of government. Rather it has to be accepted that most of the functions would continue to be shared and the appropriate task was to identify the roles which each level of government would play in those shared functions. Nearly a decade later the movement known as Prime Minister Hawke's New Federalism adopted this approach as part of its sweeping reform of intergovernmental relations, especially as a result of three Special Premiers Conferences which were the forerunner of COAG (EPAC 1990; Wiltshire 1992). The research identified criteria which would point to the role of each level, as shown in Table 12.1.

\section{Table 12.1. Criteria for Roles and Responsibilities}

\begin{tabular}{|l|l|l|}
\hline Favouring higher levels & Favouring lower levels & Indeterminate \\
\hline International responsibilities & $\begin{array}{l}\text { Subsidiarity - allocating the task to } \\
\text { the level closest to the delivery } \\
\text { point }\end{array}$ & Recognising sovereignty \\
\hline $\begin{array}{l}\text { Tasks which are indivisible and } \\
\text { achieve universality of coverage }\end{array}$ & Achieving responsiveness to clients & Alignment with revenue sources \\
\hline $\begin{array}{l}\text { Attainment of uniformity and } \\
\text { catering for mobility }\end{array}$ & $\begin{array}{l}\text { Capturing local knowledge and } \\
\text { expertise }\end{array}$ & Capacity to deliver \\
\hline Addressing equity and accessibility & $\begin{array}{l}\text { Speedy implementation and service } \\
\text { delivery }\end{array}$ & Efficiency \\
\hline $\begin{array}{l}\text { Catering for portability and } \\
\text { spillovers }\end{array}$ & Monitoring of results & Effectiveness \\
\hline Achieving national standards & Preserving uniqueness and diversity & Accountability \\
\hline Acting as an initiator / stimulator & & Linking policy to delivery \\
\hline
\end{tabular}

Source: Wiltshire 1977, ACIR 1981

The second element of the regionalism imperative is to define the regions and their boundaries. Once again there have been some well established criteria 
employed in the past. The best known is the concept of community of interest, which is the paramount criterion. A region which does not share a community of interest is not worth a 'brass razoo'. Another well-known phrase, often used in relation to local government boundaries, is that a region should be large enough to achieve economies of scale, but small enough to be responsive and encourage civic participation. A third important aspect which often appears is identity. People living in a region must feel that they share a common identity.

These may sound like theoretical concepts, but they are given reality every day in our current system of governance. Bodies such as the Electoral Commissions, Telstra, Australia Post, the Australian Bureau of Statistics, and most government agencies, employ these concepts to define their boundaries for service delivery, civic participation or community engagement. The measures which these bodies all use to delineate their regions, based on these concepts, include:

- geographical features especially rivers and mountains;

- patterns of communication;

- patterns of transport;

- degrees of remoteness;

- socio-economic homogeneity;

- cultural affinity; and

- ecology and sustainability.

Given the strong current recognition of the importance of environmental sustainability, the 'eco'-criteria will most likely dominate this list in the foreseeable future.

Once the roles of the regions and their boundaries are determined, the third fundamental stage is to consider what policy measures need to be taken to ensure their continuing viability, in order to carry out these roles. This is where genuine devolution occurs as a solution to the major problems of the existing system. With many local governments currently financially unviable, properly-resourced regions can ensure that local and regional services do not simply disappear. With state government often too remote and pre-occupied to effectively coordinate and push through new policy solutions, such properly-resourced regions can do this. However we know from the existing experience of state and local governments that some or all of the following will be required:

a. tax-sharing with the other level(s) of government, since it will never be possible to assign unique revenue sources to regions to enable them constantly to fulfil their responsibilities;

b. provision for such tax-sharing arrangements to be flexible and capable of rational review - such as in the German federation, which has a process for regular reviews of the share of taxation to go to each of the three levels of government based on rational assessment of the needs of each level; 
c. grants and subsidies, where appropriate, from other level(s) of government;

d. Community Service Obligations (CSOs) employed by government agencies of other level(s) of government should recognise the regions and where possible be delivered through them;

e. incentives from other level(s);

f. taxation allowances by other level(s) for regions where appropriate;

g. exemptions from other level(s) to relevant regions, including inappropriate regulatory arrangements; and

h. Horizontal Fiscal Equalisation to ensure all regions have the same capacity to deliver services at the same standard, at similar levels of taxation.

\section{Conclusion: identifying some models}

Given the case for a new national framework of regions, what are the options? The historical context, and trend to federal centralisation described above, now mean there are three broad models by which the creation of Australian regions could take place: within old states, by abolishing the old states, or by creating new states.

\section{Old states}

Regions would have to be created within existing state boundaries. Local governments could also be amalgamated, realigned, or grouped for this purpose. State and Commonwealth Governments would have to devolve some tasks to regions and decentralise others. Regional elected assemblies could be established with powers over resource allocation and possibly revenue-raising. This model requires minimal disruption to Australian constitutional arrangements. It would provide a new framework for coordinating and, perhaps, rationalising a growing range of existing regional governance initiatives. In particular, it could simplify the current complex system of regional governance and make it more directly accountable and responsive to the needs of each region's community. However, this model also effectively creates a fourth tier of government in the federation. If 'co-operative federalism' is relied on to develop this model, then existing experience also suggests the pace of reform may be so slow and cumbersome that the end results might never be achieved.

\section{No states}

Under this model, all the current states would be abolished. Regions and regional governments would be created in their place, most likely by amalgamation or realignment of local governments. Most public perceptions of this model see it as resulting in only two main levels of government - Commonwealth and Regions - although in practice, the Regions might still retain or re-create some form of local government (see e.g. Hurford 2004). The model would require reconfiguration of the Senate to become a House of the Regions. This model 
requires considerable constitutional change and redesign resulting in a major national referendum. Sections 123 and 128 of the Constitution mean that a majority of the electors in every State would need to support the reform in this referendum, not just a majority of electors in a majority of States. On one hand, public attitude surveys indicate a fair groundswell of opinion in both rural and urban Australia for a governance design of this kind (see Gray and Brown, this volume). On the other hand, many commentators point to the existing record of constitutional amendment in Australia, to argue that even if the reform was desirable, the divisions and uncertainties provoked by the debate might make it very difficult to achieve.

\section{New states}

Constitutionally, it is easier to pursue a third model - that of creating new states rather than abolishing old states. Under the Australian Constitution, Chapter VI (sections 121-124) deals with new states and territories. Section 124 is the operative section - it reads: 'A new State may be formed by separation of territory from a State, but only with the consent of the Parliament thereof, and a new state may be formed by the union of two or more states or parts of states, but only with the consent of the Parliaments of the States affected'. In formal terms it is the State Parliament which would decide, but a referendum would be most likely. Given the centralism trends in Australian federalism described earlier, it is important that under section 123 of the Constitution, it could also be the Commonwealth Government who initiates this referendum. Once a region is recognised by popular vote as having been separated from the existing State (to form in effect a New State), the Commonwealth Parliament then simply votes to admit that region as a new entity in the existing federal system. The Senate would also have to be reconfigured under this model but only to the extent of accommodating more states. Essentially this model involves gaining the consent of a majority of citizens in the region where the new state is to be formed, and the consent of the citizens in the State from which the new state is to be withdrawn. A virtue of using the existing constitutional provisions is that even if a referendum is used, citizens are being asked to vote directly on the substantive question - the creation of new regional governments - rather than changes to the rules in the existing Constitution.

In fact, the creation of at least some new states will in all likelihood happen naturally throughout the 21 st century. Likely candidates which have already identified themselves previously through Australian history include New England, the Riverina and North and Central Queensland. The two mainland Territories are already quasi-new states, and it is almost inevitable that the Northern Territory will be converted to full statehood, having only narrowly declined this opportunity in a referendum in 1998. Other potential regions as new states for the longer term include North-Western Australia, and much of 
Central Australia also embracing remote areas of New South Wales and Queensland.

Under this scenario the new states and/or territories effectively become the primary regions in the federal system, perhaps swallowing the local governments within their boundaries or, more likely, creating a different institutional form of local service delivery and civic involvement. This model therefore revives the original logic of federalism, with all its potential advantages.

\section{Towards a new option}

Change is upon us, as can and should be expected in any federal system. The founders intended to create a dynamic, not static, system of governance. Even if we accept that this is taking place incrementally, in line with the first model, it is important to decide where this would take us and how new regional institutions are to be reconciled with our existing system. However, there are clear reasons, based on public policy and public attitudes, for taking a longer-term view and embracing more substantial and better planned reform. The existing state governments are not viewed very favourably by their own citizens. Moreover there is a demonstrable recognition that the existing state boundaries currently make little sense. Add to this the current unassailable centripetal momentum in the Australian federation occurring through natural domestic and international economic and social trends, as well as policy drivers from all the major political parties which are now all centralist. The result is that mere variations on the status quo are not likely to deliver substantial improvements in the quality of governance under our federal system.

Taken together these factors would suggest that options based merely on the 'old States' are history. There is now both a policy logic, and a popular logic, behind a configuration of Australian governance involving two main levels: an ever-stronger national government, and regional governments which combine some policy determination and much service delivery. For this model to be saleable and feasible the result must be an Australia whose system of government appears simpler and perhaps even cheaper to its citizens, based on sustainable regions with realistic boundaries. Calculating the economic and financial benefits of such reform, and addressing any costs, are crucial. However the less constitutionally painful path to achieve this system of governance is clearly through new states rather than no states. Indeed, this approach would restore the original logic of federalism itself, while also addressing the primary concerns of federalism's greatest critics.

To be worth pursuing, this model must be seen as a substantially new option. A criticism of past proposals for new states is that they have been piecemeal, with the creation of each new state compounding rather than relieving the complications of the federal system. But there is no reason, in principle, why 
the machinery for creating new states cannot be used to bring about a substantially new, comprehensive, national system of regions, undertaken not in a piecemeal way within one or two existing states, but as part of a national reform program. This would be led by the Commonwealth Government, and undertaken with state cooperation. The new regions would employ many former state public servants, and deal directly with Canberra on most issues of funding, taxation and national regulation - a simplified, more efficient and more accountable version of what is increasingly happening now.

Why hasn't it already happened? The history of federation itself shows that the road can be a long one. In the Australian colonies, federation was widely supported, if not assumed as far back as the 1840s and 1850s, even though it took until 1901 to be secured. The momentum for the next phase of comprehensive reform to Australia's system of governance has again been growing for several decades, informed by experience. With vision and a focus on the basic principles, there is no doubt that it can be achieved.

\section{References}

Advisory Council for Intergovernment Relations 1981, Towards Adaptive Federalism, A Search for Criteria for Responsibility Sharing in a Federal System, Information Paper No. 9, AGPS, Canberra.

Aulich, C. and R. Peitsch 2002, 'Left on the shelf: local government and the Australian Constitution' Australian Journal of Public Administration, Vol. 61 (4): 14-23.

Australia, 1929, Royal Commission on the Constitution 1927-29, Report, Government Printer, Canberra.

Australia, 1959, Joint Committee on Constitutional Review, Report, Government Printer, Canberra.

Brown, A. J. 2002, 'Subsidiarity or subterfuge? Resolving the future of local government in the Australian federal system' Australian Journal of Public Administration, Vol 61 (4): 24-42.

Brown, A. J. 2003, The Frozen Continent: the Fall and Rise of Territory in Australian Constitutional Thought 1815-2003, PhD Thesis, Griffith University.

Commission on Intergovernmental Relations (Kestnbaum Commisson) 1955, A Report to the President for Transmittal to the Congress, Washington DC.

Commonwealth Grants Commission 1995, Equality in Diversity, AGPS, Canberra.

Craven, G. 2005, 'The New Centralism and the Collapse of the Conservative Constitution', Senate Occasional Lecture, Department of the Senate, Canberra, 14 October 2005. 
Craven, G. 2006, 'Are We All Centralists Now?', Address to Gilbert and Tobin Centre Constitutional Law Conference, Sydney, 24 February 2006.

Department of Urban and Regional Development 1973, Regions, AGPS, Canberra.

Economic Planning Advisory Council 1990, Towards a More Cooperative Federalism, Discussion Paper No. 90/04, AGPS, Canberra.

Hurford, C. 2004, 'A republican federation of regions: reforming a wastefully governed Australia', in W. Hudson and A. J. Brown (eds), Restructuring Australia: Regionalism, Republicanism and Reform of the Nation-State, Federation Press, Annandale NSW.

Jones, S. 2003, Beyond the Boundaries: The Contribution of Regions to Queensland's Economic Development, Information paper No. 79, CEDA, Melbourne.

La Nauze, J. 1979, Alfred Deakin: A Biography, Angus and Robertson, Sydney.

Quick, J. and R.R. Garran, 1901, The Annotated Constitution of the Commonwealth of Australia, Angus and Robertson, Sydney.

Sawer, G. 1976, Modern Federalism, Carlton, Pitman.

Sirois J. (Chairman) 1940, Royal Commission on Dominion-Provincial Relations, Report, Government Printer, Ottawa.

Spann R. N. et al 1973, Public Administration in Australia, NSW Government Printer, Sydney, Chapter 11.

Taylor, D. 2006, The States of a Nation: The Politics and Surveys of the Australian State Borders, NSW Department of Lands, Bathurst.

Wiltshire, K. (ed.) 1977, Administrative Federalism, University of Queensland Press, St. Lucia.

1980, 'Working with Intergovernmental Agreements: The Canadian and Australian Experience', Canadian Public Administration 23(3), Fall, 353379.

1991, Tenterfield Revisited: Reforming Australia's System of Government for 2001, University of Queensland Press, St. Lucia.

1992, 'Australia's New Federalism: Recipes for Marble Cakes', Publius 22(3), Summer, 165-180. 